\title{
Perceptions of SARS-COVID2-19, the Confinement Measure, and the Fear of Death from the Lethality of This Virus
}

\author{
Ivett Reyes Guillén PhD ${ }^{1 *}$, Bárbara Muñoz Alonso Reyes, Psic. TBE ${ }^{2}$, Leticia del Carmen Flores \\ Alfaro, $\mathbf{P h D}^{1}$ \\ ${ }^{I}$ Autonomous University of Chiapas, Mexico \\ ${ }^{2}$ Therapist TBE and Psychologist Professor, REINVESAD, Chiapas, México
}

*Corresponding Author: Ivett Reyes Guillén PhD, Autonomous University of Chiapas, Mexico

\begin{abstract}
This study was conducted from San Cristóbal de Las Casas, Chiapas, Mexico, with the main objective of knowing the perceptions of the Latino population regarding SARS-COVID2-19, the measure of confinement and the fear of death by the lethality of this virus. The participation of people from 08 countries, Mexico, Colombia, Ecuador, Chile, the United States, Argentina, Peru, and Bolivia was reflected. It is clear that, in order to understand the social situation generated by the pandemic, COVID, it is necessary to establish the basis for understanding of the disease, as well as the social elements that combine, in time and processes, with the health crisis. Among the main findings are: (1) the extreme measure of staying at home and the social isolation that this entails is not an action that, in Latin countries, can be generalized and sustained as a preventive measure; (2) the population has unreliable, and even alarming, information; as well as anti-system information, which in most cases invite not to take care of preventive measures; (3) attitudes towards care to prevent COVID contagion and raise the likelihood of death do not reflect the fear they claim to die, own or of relatives, the latter in greater express percentage.
\end{abstract}

Keywords: Perceptions, SARS-COVID2-19; confinement measure; fear of death

\section{INTRODUCTION}

The current pandemic situation is widely known to most of the population, due to globalization in the exchange of information and the efficiency of communication technologies, such as the internet. This ease of data has proved both beneficial and detrimental, although the response time of scientific studies and government actions has decreased, it has also generated a real scenario of psychosocial chaos, probably due to the excessive dissemination of both truthful and false information, which are also in constant contradiction.

To understand the social situation generated by the pandemic, it is necessary to establish the basis for understanding of the disease, as well as the social elements that combine, in time and processes, with the health crisis.

The disease known as COVID-19 is caused by the SARS-COV2 virus, the history of the first patients diagnosed suggest a zoonotic origin. Symptoms are observed after an average period of 5.2 days, which are: fever, cough, fatigue, headaches, sputum production, hemoptysis, dyspnea, and lymphopenia, with non-homogeneous presence among infected patients. The pathology has a cycle measured between 6 and 41 days with an average of 14 days of presence, becoming aggravated until death in some cases (Rothan and Byrareddy, 2020).

One feature that makes it difficult to approach the disease is that initial symptoms are easily found in other lower-risk diseases. At the beginning of the outbreak, the weightiest diagnostic characteristic was that the patient had been in contact with people in the outbreak area, or at risk of having been there. Subsequently, when the disease becomes pandemic this criterion disappears and symptoms being common with other diseases and different in each patient produce a nervous factor in the population.

The first case of COVID-19 is filed and published on December 31, 2019, with a low number of patients initially admitted from atypical pneumonia, all connected to a market in The Wuhan area of 
China. On 9 January 2020, it became public knowledge that the disease is the case from a new outbreak of coronavirus. It is until February 11 that the disease caused by the new virus present in more than 4 countries is given the overall name of COVID-19, in more than 4 countries, the first no imported cases are recorded at the end of February. The WHO pandemic declaration is as of 11 March 2020 (WHO, 2020).

Between the formal onset of the first cases recorded, until rise to pandemic status, approximately 2 months and 12 days occur, which is evaluated as a slow response by various means; but it means a short time, since in those 2 months the outbreak arises, the contagion nucleus is located, the identification of the causative pathogen and the anticipation of the development of the disease is made, not to mention that from the first cases not imported to the pandemic declaration elapse less than 15 days.

The view that focuses on assessing WHO's response time as negative rests largely with expedited information on what happened, which is negative for a proliferation of alarming or repetitive news that can lead to a state of nervousness, which causes a care-demanding phase.

The detection of cases outside China provoked a popular notion of a pandemic, although it was not yet declared as such by local governments and global institutions. This is caused by a misunderstanding of the terms, since the pandemic declaration must be made after two criteria: (1) the notion of cases on more than one continent and (2) that the transmission of such cases is local, not imported (Pulido, 2020).

Two social characteristics are established to respond to the pandemic by COVID-19: (1) the requirement of pandemic declarations since the beginning of the outbreak and (2) a requirement of external care, i.e. the care provided by governments towards populations. The demand for international declarations, which would assign a high terminology to the problem, relates to a massive information of the means and of alarmist structure, joining with the need for immediacy that characterizes 21 st century societies.

On the other hand, the demand for external care is a social characteristic rooted in many countries, where an uninduced threat, such as a pandemic, causes social criticism to rise in search of governments providing a satisfactory response. This is a valid social element consistent with democratic models; but it finds a destabilizing factor when the first action is the same rather than initiating preventive health and hygienic care individually, even in the absence of government statements.

This is intrinsically related to two elements in the Spanish-American area, social resentment towards 21 st century governments, and current educational lines. In this age of information, it is sought that the individual can understand and produce his own knowledge. This reality has led to current educational models promoting information to be understood and disseminated; but the ability to constantly act in populations decreases. The opposite element is the theory of reflection, where the activity of learning pursues information capacity and the generation of knowledge that allow to form habits (Israel, 2004).

Habit formation is an element that is pursued as a preventive and decreased form of contagion by Latin American governments in the face of the pandemic, which aims to reduce economic costs and increase health care capacity. While populations show a great ability to understand, judge and transmit information regarding the disease, the population's action measures are poor and reflected in their numbers of contagion, morbidity, and mortality.

On the other hand, the first element mentioned, the rancor on Latin American governments of the 21st century, is an extraordinarily complex element and finds one more expression in the overwhelming decline in the credibility of government data. This creates a lack of effective coercion for the monitoring of health security measures in the population, caused by the same widespread mistrust. This is a reality underpinned by a history of governments with malpractice, high rates of corruption and lack of satisfactory responses to various crises. The paternalistic factor of governments is also a crucial element in understanding that, since social cognition, the resolution of any event must be resolved only by the government bypassing individual responsibilities (Morales and Prego, 2002). 
In short, the COVID-19 pandemic is a fact that has affected the social fabric beyond institutions and health elements, the disease from the SARS-COV2 virus that originated in China in December 2019 and a pandemic was declared in early March 2020, when the cause of the disease was identified, its possible origin, ground zero, the hope of disease evolution and mechanisms were found to deal with it even in the absence of a vaccine.

This time is a record of response from the scientific community and health bodies. Although pandemic quality was quickly declared in the face of early cases of community transmission in America, the need for immediacy, as well as broad access to media, created a panic-based social demand. They saturated with notes the computer navigation space of individuals, between elements based on science and those that are not.

Measures to prevent and reduce contagions do not have a better picture, being faced with societies with high demand and reproduction of information; but low capacity for action, especially in terms of habits, which play an important role in each country's control strategies.

Hence the social and cognitive factor has a high impact on the proliferation of contagious diseases, which, as observed in the current health crisis, outweigh the capacities of governments for the successful response of health systems. This makes clear the misconduct of many governments and the poor actions to coordinate with society.

Since 2002 there have been 8 pandemics declared as such, of which 6 have damage to the respiratory system as the main characteristic (Cachicas,2020) of which their ability to transmit easily and quickly compared to diseases that attack other systems is inferred. It is then necessary, societies capable of confronting them, which is to deserve studies that allow the management of populations adapting them to prevention and management of health contingencies.

As a pillar of the above, large-scale health processes should be understood at the cognitive-individual and cognitive-social level, to generate better strategies for communication, prevention and action in the face of global and epidemic contingencies, where the regulatory core of health and government services, functions synchronously and orderly with the social core.

That is why this document sets out the results of an international study, representing eight Latin countries, consisting of a perception survey of SARS-COVID2-19 (COVID), the confinement measure (quarantine) and the fear of death from the lethality of this virus.

\section{RESEARCH METHOD}

This study was conducted from San Cristóbal de las Casas, Chiapas, Mexico, through an online survey, through google forms, in Spanish. It remained on the platform until the sample reached a size of no. 500 participants.

The questionnaire was structured according to the need to raise perceptions of SARS-COVID2-19 (COVID), the confinement measure (quarantine) and the fear of death from the lethality of this virus. The analysis was carried out according to the descriptive statistic that emerged from the findings and the qualitative interpretation of them.

\section{RESULTS AND ANALYSIS OF INVESTIGATIONS}

By raising information for a period of 04 weeks on the platform, up to a sample of n.500 participants, the results show that there was the participation of people living in 08 countries, $68 \%$ participants in Mexico and 32\% participants from American countries, who, in order of frequency, from highest to lowest, are Colombia, Ecuador, Chile, United States, Argentina Peru and Bolivia.

The average age of the participants is 45 years ( $\min 18$, max 84 ). In equal proportions, $50 \%$, men and women. In Latin America, the population is younger compared to the other continents fighting this pandemic. Only $9 \%$ of the Latino population is over 65 years of age, compared to $20 \%$ of the European population and 16\% of the North American population (Alvarez and Harris, 2020).

In the presence of SARS-COVID2-19, globalized humanity worked to coordinate, to find the mechanisms that reduced the impact on morbidity by this virus and avoid the high mortality involved. Since psychology, humans have been shown to acquire and maintain or modify our behaviors (VeraVillarroel, 1999). 
The results demonstrate this, but only to a certain extent, because within the preventive measures, hand washing and interpersonal distance of at least 1 meter, have been practiced for decades, in some countries more than in others: The extreme measure of staying at home, quarantined, is not an action that, in Latin countries can be generalized and sustained as a preventive measure. This is not only because of the impact on the economy from family to national and global; but by cultural elements that prevent it.

Of those who responded to the survey, $96.6 \%$ say they are aware of the current situation regarding the COVID health emergency; but when asked if they know how it affects human health, the percentage decreased to $84 \%$, i.e. they are aware, but essentially. Specific preventive health measures are known in $95 \%$ of cases.

$62 \%$ consider that the information that the government of their countries issues is diminished with respect to reality; $6 \%$ consider it to be exaggerated and 3\% that it is totally wrong. Only $29 \%$ trust that the information they receive is true.

This is linked to the factors related to the social rancor of Latin American populations towards their governments, where taking up Morales and Prego (2002) the decline in credibility of government information is an important factor in social destabilization. Regardless of the historical and corruption motivations that have resulted in this phenomenon, the non-credibility aspect related to the culture of government social resentment has taken great relevance to the management of the epidemic in these countries, an element that must be taken into account in order to improve the situation and be more successful in addressing the pandemic.

"Stay at home" measure. Specifically, on this measure $91 \%$ consider it to be a necessary measure; $9 \%$ consider it unnecessary. It is important to mention that the socio-economic conditions of these countries do not facilitate such a measure because of the high impact it generates on them, in contrast to the individual protection measures that generate preventive attitudes without diminishing their economy (Van der Pligt, 1996; IPISOS, 2020). If this measure is extended, 83\% would continue to stay at home; but the remaining percentage (17\%) would not and could even rise

In Latin America, the problem with COVID not only concerns from public health but raises several questions regarding the economic impact, in the medium and long term. This economic impact disrupts even the talent, training, experience and knowledge of academics, scientists and specifically health personnel, who are, who, as Alvarez and Harris (2020) well say, the most valuable tool in the fight to mitigate the scopes of the pandemic.

Although the percentage that they consider "staying at home" is high is a necessary measure, only $25 \%$ have stayed entirely at home; $72 \%$ have had to leave at some point to buy inputs or, for work reasons; $3 \%$ have left normally without respecting the preventive indication.

In the case of going out to visit a friend or family member, who was only $30 \%$ of respondents, they have done so because they usually frequent ( $8 \%$ ); they need help because they belong to vulnerable groups $(20 \%)$, or for boredom of being home all the time (2\%). When leaving, $87 \%$ of those who do, take care of all safety measures and $14 \%$ only take care of some, within them, the use of mouth covers 2 is not the choice.

The data indicate a tendency to stay at home, compared to leaving without respect for government measures, however, within the percentage of people leaving their homes to visit a relative or friend, $8 \%$ of these follow up on the habit of frequenting.

From the above, it is a factor of transgression to health measures motivated by a habit, in this case a social habit. Social groups have as its main component frequenting among the members of a group, that is, a social habit of sharing space and time with those close to them to maintain cohesion and, therefore, the group, same that maintain more complex social structures (Arboleya, 1954).

This includes the intrinsic need for regular social gathering in groups and talking about cultures with high intrinsic union in social groups such as Latin America, the search to break, even momentarily these meetings, is a challenge. The solution may be geared towards a communication of health measures that handle a speech to change the meeting habit and not suspend it. 
With regard to the main source of information on COVID, although for $51 \%$ it is local and international newscasts, for $49 \%$ it is social networks, which, in a non-negligible percentage, have unreliable, and even alarming information; without neglecting the anti-system information, with all their positions which, in most cases, invite not to take care of preventive measures.

The communicative structuring of news, both online and conventional media, in recent years has been decided by prayers and words of alarmist order. This, not only because of the increase in ratings and views that generate alarming publications, but because of the same communicative nature of current societies with high degrees of normalization of violent and catastrophic situations (Costa y López, 2020).

Fear of death by COVID. 69\% of respondents are afraid of death by COVID, whether it goes through their minds at some point (55\%) or, all the time they think about it (14\%). Fear of death of a family member or friend who gets sick from COVID is present in $93 \%$ of cases.

Fears are built from experiences within objective and subjective conditions. Objective manifestations, in the case at hand "death associated with COVID", form social representations that underpin the ways of perceiving, imagining and relating the individual to his environment, which is associated with a situation of danger, clearing that, in this case, it is the same situation at the global level.

However, attitudes towards care to prevent COVID contagion and raise the likelihood of death from complications themselves do not reflect the high percentage of fear they manifest from their own death or that of their family or friends. This represents a thought-action incongruity, which are found in various habits, where the force of repeated behaviors exceeds the strength of convictions, emotions or, in this case, fears.

While the fear of the death of relatives is statistically greater than their own death, the government's rancor of Latin American societies may predispose the person to blame government and/or health representatives, rather than the a priori cause, COVID-19 disease. If this hypothesis were rectified as true, it would explain the inconsistency between fear of death and poor social care to avoid it, both in cases and that we live today, as well as other diseases of high contagion and preventable with the modification of habits.

If the social scenario of the present case is set aside and the individual psychological substrate of incongruity is sought to be understood, it is sufficient to refer to what is studied by the father of modern psychology: "In the unconscious, each person is convinced of his immortality, either because he is too afraid of death, or because he is not afraid enough" (Freud, 1961).

\section{CONCLUSION}

Among the statements that we can make as conclusions of this study are:

- The extreme measure of staying at home, quarantined, is not an action that, in Latin countries, can be generalized and sustained as a preventive measure; explained both by the serious economic impact for these countries with high rates of marginalization and poverty; cultural elements that act as barriers to the search for behavior change for public health.

- $96.6 \%$ of respondents, say they are aware of the current situation regarding the COVID health emergency; but when asked if they know how it affects human health, the percentage decreased to $84 \%$, i.e. they are aware, but essentially.

- $62 \%$ consider that the information that the government of their countries issues is diminished from reality; $6 \%$ consider it to be exaggerated and 3\% that it is totally wrong. Only $29 \%$ trust that the information they receive is true. We explain this by linking it to the social resentment of Latin American populations towards their governments, where the decline in credibility of government information is an important factor in social destabilization and is a central factor in the management of the epidemic in those countries.

- On the other hand, social groups have, as a main component, frequent themselves among the members of a group, sharing spaces and times elements that maintain complex social structures. It is therefore complex to remain under social isolation imposed. 
- Regarding the main source of information about COVID, for $51 \%$ are local and international newscasts and for $49 \%$ it is social networks. They have unreliable, and even alarming information; without neglecting the anti-system information, with all their positions which, in most cases, invite not to take care of preventive measures.

- $69 \%$ of respondents are afraid of DEATH by COVID. And the fear of the death of a family member or friend who gets sick from COVID is present in $93 \%$ of cases.

- Paradoxically, attitudes toward care to prevent COVID contagion and raise the likelihood of death from complications do not reflect the fear they express about their own death or that of their family and friends. This reality extends to various habits, where the force of repeated behaviors exceeds the strength of convictions, emotions, or fears.

\section{REFERENCES}

[1] Rothan, Hussin A. y Byrareddy, Siddappa N. (2020) "The epidemiology and pathogenesis of coronavirus disease (COVID-19) outbreak" Journal of Autoimmunity. Vol.109. No.05. EUA

[2] WHO (2020). Organización Mundial de la Salud. "Cronología de la respuesta de la OMS a la COVID-19" última actualización a 30 de junio del 2020. Portal de información y declaraciones, consultado electrónicamente en https://www.who.int/es/news-room/detail/29-06-2020-covidtimeline en julio del 2020

[3] Pulido, S. (2020) “¿Cuál es la diferencia entre brote, epidemia y pandemia? Artículo de investigación para Gaceta Medica. 12 de marzo del 2020. Consultado electrónicamente en https://gacetamedica. com/investigacion/cual-es-la-diferencia-entre-brote-epidemia-y-pandemia/ en Julio del 2020.

[4] Israel Núñez, P. (2004) "Las necesidades de información y formación: perspectivas socio-psicológica e informacional" ACIMED Vol.12, No.5. Recuperado en Julio 2020 de http://scielo.sld.cu/scielo.php? script=sci_arttext\&pid=S1024-94352004000500004\&lng=es\&tlng=pt.

[5] Morales López, E. y Prego Vazquez, G. (2002) "Entrevistas electorales en las campañas políticas para la presidencia del gobierno de 1996 y 2000" Editorial Arco/Libros. Chile

[6] Cachicas, V. (2020) "El mundo está alerta a epidemia por neumonías causadas por el coronavirus relacionado al consumo de animales silvestres: la historia se repite" Rev. Inst. Salud Pública Chile. Vol.4, No.1. Chile. DOI: doi.org/10.34052/rispch.v1i1.91

[7] Alvarez, Reinaldo Pierre, \& Harris, Paul R. (2020). COVID-19 en América Latina: Retos y oportunidades. Revista chilena de pediatría, 91(2), 179-182. https://dx.doi.org/10.32641/rchped.vi91i2.21 57

[8] Vera-Villarroel, P. (1999). Psicología del Aprendizaje y sus aplicaciones prácticas. Universidad Miguel de Cervantes.

[9] Van der Pligt J. Risk perception and self-protective behavior. Eur Psychol 1996; 1:34-43.

[10] IPSOS. Public opinion on the COVID-19 pandemic. IPSOS. 2020. Available https://www.ipsos.com/en/ public-opinion-covid-19-outbreak: (accessed 3 Apr 2020).

[11] Arboleya, E.G. (1954) "Teoría del Grupo Social”. Revista de Estudios Políticos. Vol.1, No.76. España.

[12] Costa Sánchez, C y López García X. (2020) "Comunicación y crisis del coronavirus en España. Primeras lecciones" Revista Internacional de Información y Comunicación. Vol.29, No.3. https://doi.org/10.3145 /EPI

[13] Freud, S. (1961). Beyond the pleasure principle. New York: Liveright Publishing Company.

Citation: Ivett Reyes Guillén PhD, et.al. "Perceptions of SARS-COVID2-19, the Confinement Measure, and the Fear of Death from the Lethality of This Virus" International Journal of Research in Sociology and Anthropology (IJRSA), vol 6, no. 2, 2020, pp. 21-26. doi: https://doi.org/10.20431/2454-8677.0602004.

Copyright: () 2020 Authors. This is an open-access article distributed under the terms of the Creative Commons Attribution License, which permits unrestricted use, distribution, and reproduction in any medium, provided the original author and source are credited. 